\section{Heritability Estimates of Turf-type Characteristics in Buffalograss}

\author{
S.J. Browning and T.P. Riordan ${ }^{2}$ \\ Department of Horticulture, University of Nebraska, Lincoln, NE 68583-0724
}

\section{R.K. Johnson ${ }^{2}$}

Department of Animal Science, University of Nebraska, Lincoln, NE68583-0908

\author{
J. Johnson-Cicalese ${ }^{3}$ \\ Department of Horticulture, University of Nebraska, Lincoln, NE68583-0724
}

Additional index words. Buchloë dactyloides, drought resistance, turfgrass

\begin{abstract}
Buffalograss [Buchlö̈ dactyloides (Nutt.) Engelm] is a drought-resistant, dioecious species, native to the Central Great Plains, which shows excellent potential as a lowmaintenance turfgrass. Although buffalograss can be propagated vegetatively, there is a need for seeded turf-type cultivars. To assist in developing seeded cultivars, heritabilities of turf characteristics were estimated. Heritabilities from maternal half-sib analyses ranged from $h^{2}=0.04 \pm 0.03$ for the 1988 uniformity rating to $h^{2}=0.62 \pm 0.26$ for the 1989 spring color rating. Heritability estimates calculated from offspring-parent regression were also variable and generally lower than maternal half-sib analysis. The results suggest that some turf characteristics are highly heritable and that growing conditions markedly affect heritability estimates.
\end{abstract}

Buffalograss is a dioecious, drought-resistant perennial grass native to the Central Great Plains of North America (Wenger, 1943). Development of buffalograss cultivars with turf-type characteristics to partially replace currently used species would reduce the amount of water used for turf maintenance in the United States (Riordan et al., 1993). A major obstacle to the widespread use of buffalograss has been the unavailability of seed that produces a uniform, attractive turf (Huff and Wu, 1987). Buffalograss populations have shown considerable variability for turf characteristics, such as color, density, leaf texture, date of spring green-up, number of stolons, spread rate, and resistance to disease, insects, and drought (Beetle, 1950). By estimating the variance components of these turf characteristics between the parent selections and seeded progeny, the reliability of the phenotypic value, or heritability, can be predicted. Heritability can be a useful. tool in breeding; selecting for characteristics with high heritability will likely result in greater gains in the offspring than when heritability is low. The objective of this study was to estimate the heritability of turf characteristics in buffalograss using maternal half-sib analysis and offspring-parent regression.

Received for publication 19 Apr. 1993. Accepted for publication 21 Sept. 1993. Journal Paper no. 10005, Agricultural Research Division, Univ. of Nebraska. Research supported in part by the U.S. Golf Association and the Nebraska Turfgrass Foundation. The cost of publishing this paper was defrayed in part by the payment of page charges. Under postal regulations, this paper therefore must be hereby marked advertisement solely to indicate this fact.

'Graduate Student,

${ }^{2}$ Professor.

${ }^{3}$ Project Coordinator.

\section{Materials and Methods}

Plant material for the field study came from seed harvested from 10 female buffalograss lines at the John Seaton Anderson Turfgrass Research Facility, Univ. of Nebraska Agricultural Research and Development Center, Mead. The 10 buffalograss lines chosen and low growth habit. Selections NE 84-104, $205,409,502,512$, and 609 had been collected in Texas; NE 84-903 in Nebraska; NE 84-800 in Arizona; and NE 84-25-2 and NE 84-36-2 in Colorado. Plants were open-pollinated by a population of male plants of the same general background. Burs were harvested from each line by mowing with a rotary mower at $7.5 \mathrm{~cm}$, collecting clippings, and vacuuming. The plots were mowed again at $2.5 \mathrm{~cm}$ and revacuumed. Burs were separated from grass clippings using a seed cleaner (Precision Instruments, Lincoln, Neb.) and then sieves (mesh sizes 4.2 and $8.4 \mathrm{~mm}$ ). Caryopses were mechanically removed from burs using a barley pearler (model 109 B/B; Seedburo Equipment Co., Chicago) and separated from the empty burs using another series of sieves (pore sizes 2.1 to $3.2 \mathrm{~mm}$ ) and a seed blower (model 757; Seedburo). Progeny from each of the 10 lines were established from individual caryopses planted in flats containing thirty-six $5 \times 5$-cm cells, using a standard greenhouse potting mixture. During 3 months in the greenhouse, the seedlings received two applications of a commercial starter fertilizer $(19 \mathrm{~N}-26 \mathrm{P}-5 \mathrm{~K})$ at $5 \mathrm{~g} \mathrm{~N} / \mathrm{m}^{2}$ and daily irrigation.

In early May 1988, seedlings were planted in the field in a randomized complete block design with three blocks. The 10 female buffalograss parent lines were the treatment factors and were randomized as rows in each block. Each row contained $\approx 100$ plants per showed an attractive color, high density, vigor, line, planted on 1-m centers. Vegetative plugs of the female parent line were included in each row, spaced every tenth plant. After planting, the field was treated with 2-chloro-4,6bisethylamino- 1,3,5-triazine (simazine) at 0.1 $\mathrm{g}$ a.i. $/ \mathrm{m}^{2}$ for preemergent weed control. A single application of fertilizer was applied at 5 $\mathrm{g} \mathrm{N} / \mathrm{m}^{2} 3$ weeks after planting. Irrigation was applied as needed to prevent visible drought stress symptoms for the first 4 weeks after planting.

The variables measured during 1988 and 1989 were:

Roots per node: average number of live and dead roots at three nodes on three randomly chosen stolons.

Vertical elongation rate: centimeters of vertical growth 5 days after mowing at $6 \mathrm{~cm}$.

Uniformity: an estimate of even appearance immediately after mowing, based on a 1 to 9 scale, where $9=$ best.

Stolon count: total number of stolons that contained three node and internode sections.

Color: rated on a 1 to 9 scale, where $1=$ brown or light tan, $5=$ a typical gray-green buffalograss color, and 9 = a blue-green color typical of Kentucky bluegrass.

Quality: rated on a 1 to 9 scale, where 9 $=$ best overall uniformity, density, spread rate, texture, and smoothness.

Diameter: total spread, in centimeters, of each plant.

Analysis of variance was calculated for each variable. Heritability was estimated for the 10 female buffalograss lines using offspring-parent regression and maternal half-sib analysis. Offspring-parent regression used only the maternal parent since the paternal parent was unknown. Heritability was calculated using the relationship $h^{2}=2 b_{o, p}$, where $b_{o . p}=$ the regression of offspring values on the maternal values. Standard errors for the heritability of offspring-parent regression were computed using the standard error of the regression multiplied by two.

Maternal half-sib analysis used the following model (Falconer, 1986): $Y_{i \mathrm{ik}}=\mu+\mathrm{T}_{\mathrm{i}}+\mathrm{B}_{\mathrm{i}}$ $+(\mathrm{TB})_{\mathrm{ij}}+\mathrm{E}_{\mathrm{ijk}}$, where $\mathrm{Y}_{\mathrm{ijk}}=$ observation of the $\mathrm{k}^{\text {th }}$ plant in the $\mathrm{j}^{\text {th }}$ block and the $i^{\text {th }}$ line; $\mu=$ overall mean; $T_{i}=$ female parent line effect; $B_{i}$ $=$ block effect; $(\mathrm{TB})_{\mathrm{ij}}=$ female parent line $\mathrm{x}$ block interaction; and $\mathrm{E}_{\mathrm{ijk}}=$ random error effect within lines. A mixed model was used with all effects being random except the block effect, which was fixed. The model had the following expected mean squares (source, degrees of freedom, expected mean square, respectively): block, $\mathrm{r}-1, \sigma_{\mathrm{w}}^{2}+\operatorname{s} \sigma_{\mathrm{rs}}^{2}+\mathrm{ts}\left(\Sigma \mathrm{B}_{\mathrm{j}}^{2} /\right.$ $\mathrm{r}-1$ ); between lines, $\mathrm{t}-1, \boldsymbol{\sigma}_{\mathrm{w}}^{2}+\mathrm{rs} \boldsymbol{\sigma}_{\mathrm{T}}^{2}$; block $\times$ line, $(\mathrm{r}-1)(\mathrm{t}-1), \sigma_{\mathrm{w}}^{2}+\mathrm{s} \sigma_{\mathrm{rB}}^{2}$; within lines, $\operatorname{rt}(\mathrm{s}$ $-1), \sigma_{w}^{2}$; where $\mathrm{r}=$ number of blocks, $\mathrm{t}=$ number of female lines, and $s=$ number of progeny per line.

Variances were calculated using the harmonic means of $n_{L}=$ number of individuals per line and $\mathrm{n}_{\mathrm{B} \times \mathrm{L}}=$ number of individuals per block 
$\times$ line combination. This procedure was followed to remove the effect of varying family size. Heritability for the maternal half-sibs was calculated using the formula $h^{2}=4 \sigma_{\mathrm{T}}^{2} / \sigma_{\mathrm{P}}^{2}$, where $\sigma_{\mathrm{T}}^{2}=$ maternal variance and $\sigma_{\mathrm{p}}^{2}=$ total variance. Standard error for the half-sib analysis was calculated using the sampling variance of the intraclass correlation of maternal half-sibs (Falconer, 1986): $\sigma_{\mathrm{t}}^{2}=2[1+(\mathrm{n}-$ 1) $t]^{2}(1-t)^{2} / n(n-1)(N-1)$, where $t=h^{2} / 4, n=$ number of individuals per family, and $\mathrm{N}=$ number of families. The standard error of the heritability was then calculated as 4 times the standard error of the intraclass correlation.

\section{Results and Discussion}

Comparison of offspring-parent regression and maternal half-sib analysis generally showed that heritability estimates were higher when calculated from the maternal half-sib analysis (Tables 1 and 2). This result was particularly evident in the second year of the study (Table 2). The analysis of maternal half-sibs often gives a high estimate of heritability due to the various maternal effects common to all progeny within a line.

In 1988 (Table 1), the highest heritability estimates by offspring-parent regression were roots per node, vertical elongation rates, and uniformity. When analyzed using maternal half-sib analysis, the following three categories exhibited the highest heritabilities: vertical elongation rates, roots per node, and the July color rating.

In 1989 (Table 2), the highest heritabilities estimated by offspring-parent regression were the August vertical elongation rate, and the July and August color ratings. Maternal half-sib analysis showed ratings for spring color, July and August quality, and uniformity had the highest heritability estimates.

It is interesting that vertical elongation rates on .13 and 27 Sept. 1988 and on 16 Aug. 1989 show a higher heritability than the vertical elongation rate taken on 17 July 1989. Perhaps this was because plants had a greater vertical elongation rate later in the season; thus, in July there was a larger relative error.

Heritabilities of quality from offspringparent regression in 1988 started at h' $=-0.03$ \pm 0.05 and increased only slightly throughout the summer. These initial low heritabilities may be due to the slow start made by the semidormant plugs of the parent plants compared with the more vigorous seedlings of the progeny. Heritabilities estimated for quality from the maternal half-sib analysis remained fairly constant throughout the year. Heritability of quality for both offspring-parent regres-

Table 1 . Heritability and phenotypic variance of progeny estimated for 10 female buffalograss lines using offspring-parent regression and maternal half-sib analysis on characteristics evaluated in 1988.

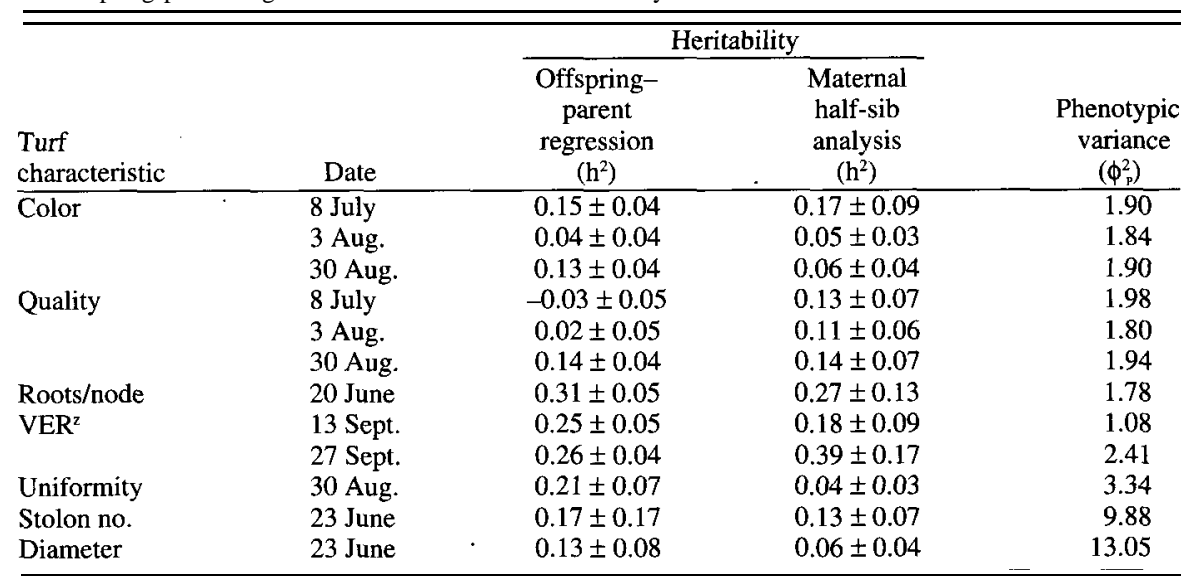

${ }^{2} \mathrm{VER}=$ vertical elongation rate.

Table 2. Heritability and phenotypic variance of progeny estimated for 10 female buffalograss lines using offspring-parent regression and maternal half-sib analysis on characteristics evaluated in 1989.

\begin{tabular}{|c|c|c|c|c|}
\hline \multirow[b]{2}{*}{$\begin{array}{l}\text { Turf } \\
\text { characteristic }\end{array}$} & \multirow[b]{2}{*}{ Date } & \multicolumn{2}{|c|}{ Heritability } & \multirow[b]{2}{*}{$\begin{array}{c}\text { Phenotypic } \\
\text { variance } \\
\left(\phi_{\mathrm{p}}^{2}\right)\end{array}$} \\
\hline & & $\begin{array}{l}\text { Offspring- } \\
\text { parent } \\
\text { regression } \\
\left(h^{2}\right)\end{array}$ & $\begin{array}{c}\text { Maternal } \\
\text { half-sib } \\
\text { analysis } \\
\left(\mathrm{h}^{2}\right)\end{array}$ & \\
\hline Spring color & 5 June & $0.10 \pm 0.03$ & $0.62 \pm 0.26$ & 1.74 \\
\hline \multirow[t]{3}{*}{ Color } & 5 July & $0.35 \pm 0.04$ & $0.29 \pm 0.14$ & 1.74 \\
\hline & 11 Aug. & $0.35 \pm 0.04$ & $0.28 \pm 0.13$ & 1.57 \\
\hline & 6 Sept. & $0.01 \pm 0.03$ & $0.11 \pm 0.06$ & 1.46 \\
\hline \multirow[t]{3}{*}{ Quality } & 5 July & $0.12 \pm 0.03$ & $0.44 \pm 0.19$ & 1.86 \\
\hline & 11 Aug. & $0.09 \pm 0.02$ & $0.36 \pm 0.16$ & 1.97 \\
\hline & 6 Sept. & $0.01 \pm 0.02$ & $0.24 \pm 0.11$ & 1.78 \\
\hline Roots/node & 13 June & $0.05 \pm 0.04$ & $0.11 \pm 0.06$ & 1.44 \\
\hline \multirow[t]{2}{*}{$\mathrm{VER}^{2}$} & 17 July & $0.12 \pm 0.06$ & $0.08 \pm 0.05$ & 3.70 \\
\hline & 16 Aug. & $0.38 \pm 0.04$ & $0.25 \pm 0.12$ & 1.39 \\
\hline Uniformity & 5 July & $0.07 \pm 0.03$ & $0.38 \pm 0.17$ & 1.87 \\
\hline Diameter & 13 June & $0.01 \pm 0.04$ & $0.29 \pm 0.13$ & 28.45 \\
\hline
\end{tabular}

${ }^{2}$ VER $=$ vertical elongation rate.

sion and maternal half-sib analysis declined steadily in 1989 .

In 1988, heritabilities for color were higher in July than on 3 Aug. In 1989, heritabilities for color estimated through offspring-parent regression were fairly high in July and August, but then showed a marked decline on 6 Sept. A similar pattern was evident in the maternal half-sib analysis.

From the results obtained, we conclude that vertical elongation exhibits a high heritability between offspring and parent, especially later in the growing season. For several characteristics measured, the time of year and environmental conditions seem to be important in estimating heritability. Evaluations should probably be made when buffalograss is actively growing and not under environmental stress. Heritabilities estimated under active growth appear to be higher and may better reflect the improvement that would be possible through breeding and selection.

\section{Literature Cited}

Beetle, A.A. 1950. Buffalograss-Native of the shortgrass plains. Wyoming Agr. Expt. Sta. Bul. 293:1-31.

Falconer, D.S. 1986. Introduction to quantitative genetics. Longman Scientific and Technical, Essex, England. p. 163-184.

Huff, D.R. and L. Wu. 1987. Sex expression in buffafograss under different environments. Crop Sci. 27:623-626.

Riordan, T.P., S.A. de Shazer, J.M. Johnson-Cicalese, and R.C. Shearman. 1993. An overview of breeding and development of buffalograss for golf course turf. Intl. Turfgrass Soc. Res. J. 7:816 822.

Wenger, L.E. 1943. Buffalograss. Kansas Agr. Expt. Sta. Bul. 321:1-78. 